\title{
Effect of Changes in Precipitants Volume Ratios on Heavy Organics Precipitation from Crude Oil at Different Production Locations using binary Mixtures of Aliphatic Hydrocarbons
}

\author{
Godwin A. Udourioh*1,3, Ozioma Achugasim ${ }^{1}$, Samuel E. Ofodile ${ }^{2}$ and I. P. Okoye ${ }^{1}$ \\ Department of Pure and Industrial Chemistry, Faculty of Sciences, University of Port Harcourt, \\ P. M. B. 5323, Choba, Rivers State, Nigeria ${ }^{1}$ \\ Institute of Petroleum Studies (IPS), University of Port Harcourt, Nigeria ${ }^{2}$ \\ Department of Pure and Applied Chemistry, College of Natural and Applied Sciences, Veritas University, Abuja, \\ Nigeria $^{3}$ \\ *Corresponding Author’s e-mail: gadiurioh@yahoo.com
}

\begin{abstract}
The effects of changes in ratios of n-alkane precipitants on the quantity of heavy organics precipitated at wellhead, separator and flowline during petroleum production was studied. Crude oils from three (3) wells at Sapele oil field, Niger Delta, Nigeria, were sampled. Gravimetric titration with single and corresponding binary mixtures of low molecular weight n-alkane precipitants $\left(\mathrm{C}_{5}\right.$ and $\left.\mathrm{C}_{6}\right)$ at different ratios was used to generate the heavy organic precipitates. The results obtained from the 0:1, 1:3, 1:2, 1:1, 2:1, 3:1 and 1:0 ratios of $\mathrm{C}_{5}: \mathrm{C}_{6}$ binary mixtures of precipitants showed a consistent increase in the quantity of heavy organic precipitate at wellhead while the Separator recorded the least in all the three reservoirs. From the result obtained, it is important to closely monitor the operational pressure and temperature at the different locations of the production system and to ensure that the operational pressure and temperature at wellhead is higher than that of the flowline and that of flowline higher than the separator to prevent heavy organic precipitation and deposition.
\end{abstract}

Keywords: Precipitation, Heavy Organics, Precipitants, n-alkane, Crude oil, Ratios, Binary mixtures, Asphaltene.

\section{INTRODUCTION}

Petroleum fluids produced from various environments such as onshore or offshore reservoirs experience significant changes in pressure, temperature and composition as they flow from reservoir pore spaces to production facilities. These changes in temperature, pressure and composition may lead to heavy organics precipitation and deposition. Heavy organics such as asphaltenes, waxes, resins and aromatics, if precipitated and deposited during petroleum production, may result in storage capacity loss, equipment fouling and damages, blockages of reservoirs and pipelines and reduction of well productivity with the attendant economic implication. Pressure depletion and compositional changes have been reported to have direct effects on asphaltene precipitation while decrease in temperature directly affects wax precipitation [1, 2,3]. On the other hand, studies have also shown that there is no precipitation of asphaltenes without co-precipitation of resins, waxes and other solids: a justification for the term "Heavy Organics" [4]. 


\section{International Advanced Research Journal in Science, Engineering and Technology \\ ISO 3297:2007 Certified \\ Vol. 5, Issue 1, January 2018}

Change in the composition of the medium in which the amphiphiles or basic building blocks of asphaltene and other heavy organics precipitate is a major factor that induces precipitation and deposition of heavy organics [5, 6].

The study of asphaltene precipitation upon addition of $n$-alkane solvents to stock-tank oils has often been used in the understanding of the precipitation phenomena. Addition of paraffinic compounds shifts the solubility of asphaltenes in the bulk oil because its solvent power affects interactions among asphaltenes and resins. If the paraffinic compounds are good solvents for resins but not for asphaltenes, as the volume of diluents increases both the interaction between resins and asphaltenes and the capacity of the former to stabilize the asphaltene molecules as small aggregates becomes weak, causing asphaltenes to precipitate [7].

Furthermore, since interactions such as obstruction to movement or retardation between the n-alkane solvents molecules and the large heavy organic units will be small due to the difference in size and molecular weight, shielding effect of the polar units of the aromatics and resins is reduced [6].

The recent work by Iroegbu et al. [8] established the fact that n-alkane volume ratios do affect the amount of heavy organics (HOs) precipitated at any given combination and total volume of the precipitant mixtures, and that the susceptibility of crude oil to precipitate heavy organics in significant quantity, capable of creating a problem in the field will be a function of the volume ratio of the individual n-alkane present in the crude oil. However, reported studies did not extend to crude oils sampled from various locations of the production line.

In this work, the effect of changes in the volume ratios of n-pentane and n-hexane precipitant binary mixtures on the quantity of heavy organics precipitated at wellhead (WH), Flowline (FL) and separator (SR) from three (3) different wells during petroleum production was studied.

\section{MATERIALS AND METHOD}

The materials used for this work were: Crude oil samples, n-pentane, n-hexane, analytical balance (AB54 meter with accuracy of $0.0001 \mathrm{~g}$ ), Mechanical shaker (staurt flask shaker), Vacuum pump and vacuum filtration unit (leyboldheraeus pump), Digital density analyser (ASTM D4052), Automated cloud point tester (ASTM D2500), Oven, heating mantle, thermometer $\left(360^{\circ} \mathrm{C}\right.$ range $)$, water bath, separating funnel, membrane filter $(0.45 \mu \mathrm{m}$ pore size; $47 \mathrm{~mm}$ diameter as specified by ASTM), stop clock, glass wares and Atmospheric distillation unit.

\section{Sample Collection and Preparation}

The crude oil samples were collected at the wellhead, separator and flowline of three different oil wells in Sapele oil field, Niger Delta, Nigeria. The oil samples were separated from the associated water, put into sample bottles and stored in a refrigerator for further analysis.

\section{Crude oil Assay}

Some physical properties of the crude oil samples were measured. The properties include: Kinematic viscosity, Density, Specific gravity and API gravity.

Kinematic Viscosity: is an important fluid property when analysing liquid behaviour and fluid motion near solid boundaries. It is the fluid resistance to flow. In this work, kinematic viscosity was determined based on ASTM D445 standard procedure. The density of the oil sample was noted using Aton Paar. The sample was poured into appropriate capillary tube. The Kinematic viscosity tester was turned on and the temperature set at $40^{\circ} \mathrm{C}$. The sample capillary tubes were inserted and allowed to stand for 15 minutes. The time taken for the oil to flow from line "a" to line "b" of the capillary was recorded. The kinematic viscosity was then calculated using the expression: 


\section{International Advanced Research Journal in Science, Engineering and Technology \\ ISO 3297:2007 Certified \\ Vol. 5, Issue 1, January 2018}

Kinematic viscosity $=\frac{\text { Area of fluid flow }}{\text { Time taken }} \mathrm{m}^{2} / \mathrm{s}$ and expressed in centistokes.

Note: $1.0 \mathrm{~m}^{2} / \mathrm{s}=10000$ stokes $=1000000$ centistokes.

Density, Specific gravity and API gravity: The oil density was determined using a digital density analyser designed in line with American Society for Testing and Material (ASTM D4052) specification. Approximately $2 \mathrm{ml}$ of the crude oil sample was introduced into an oscillating sample tube of the digital analyser and the change in the oscillating tube in conjunction with calibration data was used to determine the density, specific gravity and API gravity.

\section{Distillation of the crude oil Samples}

The crude oil samples were distilled using atmospheric distillation unit to get rid of the lighter fractions. The crude oil samples were heated up to $350^{\circ} \mathrm{C}$ atmospheric equivalent temperature (AET) and the residue left to cool and stored in air tight flasks for subsequent analysis.

\section{Heavy Organic Precipitation}

The precipitation of heavy organics from the crude oil samples was carried out by gravimetric titration experiments similar to those implemented by Kokal et al. [9] and Buenrostro-Gonzalez et al. [1] and modified ASTM/IP methods. $0: 1,1: 3,1: 2,1: 1,2: 1,3: 1$ and 1:0 (v/v) ratios of $\mathrm{n}$-pentane vs $\mathrm{n}$-hexane $\left(\mathrm{C}_{5}: \mathrm{C}_{6}\right)$ binary mixtures each at $30 \mathrm{mls}$ constant total volume was added to about $2 \mathrm{~g}$ of oil each in an appropriate flask. The mixtures were shaken for $30 \mathrm{mins}$ using mechanical shaker and allowed to stand for 48hrs. After which the solution of the n-alkanes and deasphalted oil was filtered using a vacuum pump system with a $0.45 \mu \mathrm{m}$ membrane filter fitted in a Buchner funnel/Buchner flask and connected to the vacuum pump. The flask was rinsed with small volumes of the corresponding binary mixtures of $n$ alkane solvents and poured on the membrane filter to eliminate the residual oil. The membrane filter with the precipitated material was dried in a vacuum oven at 0.1 bar (gauge pressure) and $333 \mathrm{k}$ over $2 \mathrm{hrs}$ and finally weighed to determine the heavy organic mass precipitate. The weight percent heavy organic precipitate was calculated using the expression:

$$
\frac{\text { weight of HO precipitate }}{\text { Weight of crude oil }} \times \frac{100}{1}
$$

All procedures were repeated for wellhead, separator and flowline crude oil samples and for the three different oil wells.

\section{RESULTS AND DISCUSSION}

The results of the physicochemical analysis of the crude oil samples are presented in Table I. The results show that the density of the crude oils obtained from Sapele well one (SAPW1), Sapele well two (SAPW2) and Sapele well three (SAPW3) wellhead (WH), separator (SR) and flowline (FL) ranges from 0.83 to $0.85 \mathrm{~g} / \mathrm{cm}^{3}$ at $15^{\circ} \mathrm{C}$. The specific gravity at $15.5^{\circ} \mathrm{C}$ also ranges from 0.83 to 0.85 . The American Petroleum Institute (API) gravity ranges from $35^{\circ}$ to $39^{\circ}$. This implies that the wellhead, separator and flowline oil samples from the three wells (SAPW1, SAPW2 and SAPW3) range from medium to light crude oils.

The kinematic viscosity of the crude oils at $40^{\circ} \mathrm{C}$ in centistoke (cst) ranges from 4.63 to 7.90 . This shows that the crude oils have less resistance to flow.

\section{Heavy Organic Precipitation}

The results of the experiments at $29^{\circ} \mathrm{C}$ and atmospheric equivalent pressure are presented on tables 2,3 and 4 and analysed graphically in figures 1,2 and 3 .

From the SAPW1 results presented in Table II and graphically analysed in figure 1, the 1:0, 3:1, 2:1, 1:1, 1:2, 1:3 and $0: 1$ ratios of $\mathrm{C}_{5}: \mathrm{C}_{6}$ binary mixtures yielded $3.15 \%, 1.73 \%, 1.30 \%, 2.01 \%, 1.38 \%, 1.25 \%$ and $1.16 \%$ precipitates 


\section{International Advanced Research Journal in Science, Engineering and Technology \\ ISO 3297:2007 Certified \\ Vol. 5, Issue 1, January 2018}

respectively at the wellhead $(\mathrm{WH}) ; 2.53 \%, 1.29 \%, 1.19 \%, 1.81 \%, 1.21 \%, 1.06 \%$ and $0.94 \%$ precipitates respectively at the flowline $(\mathrm{FL})$, then $2.06 \%, 1.15 \%, 0.92 \%, 1.43 \%, 0.90 \%, 0.78 \%$ and $0.72 \%$ precipitates respectively at the separator (SR).

The result shows that the highest precipitate at any location of the production system such as wellhead, flowline and separator is recorded with 1:0 ratios which are 100\% lower carbon number of the mixtures. As the higher carbon number was added to the mixture the quantity of precipitate started to decrease down to a minimum at 2:1 ratio with a subsequent increase to a maximum at 1:1 ratio. Further addition of the higher carbon number again reduces the precipitate to another minimum at $1: 2$ ratio of $\mathrm{C}_{5}: \mathrm{C}_{6}$ binary mixture and finally to the least precipitate at $0: 1$ ratio which is the $100 \%$ higher carbon number. This observation is in line with previous reports that precipitation of heavy organics using binary mixtures of n-alkane is a three-stage phase transition: solid-liquid phase transition, liquid-solid phase transition or colloidal formation and eventual collapse of the resulting colloids or solid-liquid phase transition [10, 11]. The phase transitions are not in any way affected by the different locations of the production system.

The result as shown in figure 1 indicates that the wellhead (WH) recorded the highest precipitates irrespective of the ratios used followed by the flowline and the separator. At 1:0 ratio of $\mathrm{C}_{5}: \mathrm{C}_{6}$ binary mixture, the wellhead produced $3.15 \%$ precipitates while the flowline and separator yielded $2.53 \%$ and $2.06 \%$ respectively. At the minima, $2: 1$ ratios, the wellhead yielded $1.30 \%$ precipitates while the flowline and separator produced $1.19 \%$ and $0.92 \%$ respectively. Again at the maxima, 1:1 ratios, the wellhead produced $2.01 \%$ precipitates while the flowline and separator recorded $1.81 \%$ and $1.43 \%$ respectively. Similar trends were also observed in SAPW2 and SAPW3 as shown in figures 2 and 3.

The continuous injection of production chemicals and gases such as carbon (iv) oxide $\left(\mathrm{CO}_{2}\right)$ may be responsible for the high heavy organics (HOs) precipitates recorded at the wellhead. According to Yen and Chilingarian [12], asphaltene precipitation increases as the volume of $\mathrm{CO}_{2}$ available to the crude oil increases during later stages of $\mathrm{CO}_{2}$ injection or stimulation. The most noticeable primary locations of asphaltene precipitation and deposition effect are the wellhead, wellbore and pump regions.

Although, $\mathrm{CO}_{2}$ is known in destabilizing asphaltene equilibria by lowering $\mathrm{pH}$, changing oil composition, creating turbulence and formation of emulsions in presence of an asphaltic crude, every $\mathrm{CO}_{2}$ flood operation is also responsible for some degree of asphaltene precipitation and deposition [12].

Furthermore, pressure drop as the crude oil is forced through the wellbore may equally contribute to the high heavy organics (HOs) precipitate at the wellhead. Pressure drop is one of the important factors that influence heavy organics or solid precipitation and deposition. The effect of pressure is most intense when the crude oil is rich in light ends and occurs just above the burble point. Depending on the location of pressure drops, asphaltene precipitation and deposition may occur in different parts of the reservoir such as wellhead, flowline as well as wellbore [12].

\section{CONCLUSION}

The significant findings from this study are as follows: (a) the wellhead has the highest heavy organic precipitation tendency, followed by the flowline and the separator irrespective of the ratios of $n$-alkane precipitants binary mixtures (b) the location of the production system does not change the existing fact that HOs precipitation using binary mixtures of n-alkane is a three-stage phase transition process. The reservoirs under study should be produced at high wellhead pressure to alleviate heavy organic precipitation problems. 


\section{International Advanced Research Journal in Science, Engineering and Technology \\ ISO 3297:2007 Certified \\ Vol. 5, Issue 1, January 2018}

TABLE I

Crude oil Samples Assay

Analysis

Density $\left(\mathrm{g} / \mathrm{cm}^{3}\right) @$ $15^{\circ} \mathrm{C}$

Specific gravity@ $15.5^{\circ} \mathrm{C}$

API gravity

Kinematic Viscosity (cst)@40ㄷ
SAPW2

SAPW1

WH SR FL WH

0.8496

0.8463

0.8480

0.8396

SR

FL

0.8301

0.8371

WH

SAPW3

0.8494

0.8467

0.8474

0.8391

0.8297

0.8371

0.8443

SR

FL

35.09

35.6

35.48

37.14

39.05

37.53

0.844

0.8431

0.8440

$7.83 \quad 7.90$

7.81

$5.75 \quad 4.63$

5.71

6.56

6.45

6.58

TABLE II

Heavy organics (HO) precipitated from Wellhead (WH), Separator (SR) and Flowline (FL) crude oil samples of SAPW1 by changes in ratios of $\mathbf{n}-\mathbf{C}_{5}: \mathbf{C}_{6}$ binary mixtures.

\begin{tabular}{|c|c|c|c|c|c|c|c|c|c|}
\hline \multirow[b]{2}{*}{$\begin{array}{l}\text { Test } \\
\text { S/N }\end{array}$} & \multirow[b]{2}{*}{$\begin{array}{l}\text { Ratios } \\
\mathrm{C}_{5}: \mathrm{C}_{6}\end{array}$} & \multirow[b]{2}{*}{$\begin{array}{l}\text { v/v ratio } \\
\mathrm{C}_{5}: \mathrm{C}_{6}\end{array}$} & \multirow[b]{2}{*}{$\begin{array}{l}\text { Wt.of } \\
\text { crude(g) }\end{array}$} & \multicolumn{2}{|c|}{$\begin{array}{l}\text { SAPW1 wellhead } \\
\text { (WH) }\end{array}$} & \multicolumn{2}{|c|}{$\begin{array}{c}\text { SAPW1 Separator } \\
\text { (SR) }\end{array}$} & \multicolumn{2}{|c|}{$\begin{array}{l}\text { SAPW1 Flowline } \\
\text { (FL) }\end{array}$} \\
\hline & & & & $\begin{array}{l}\text { Wt. of HO } \\
\text { ppt. (g) }\end{array}$ & $\begin{array}{l}\text { Wt. \% HO } \\
\text { ppt. (\%) }\end{array}$ & $\begin{array}{l}\text { Wt. of } \\
\text { HO ppt. } \\
\text { (g) }\end{array}$ & $\begin{array}{l}\text { Wt.\% } \\
\text { HO ppt. } \\
(\%)\end{array}$ & $\begin{array}{c}\text { Wt. } \\
\text { ofHO } \\
\text { ppt. (g) }\end{array}$ & $\begin{array}{l}\text { Wt. } \% \\
\text { HO ppt. } \\
(\%)\end{array}$ \\
\hline 1 & $0: 1$ & $0: 30$ & 2.00 & 0.0232 & 1.16 & 0.0144 & 0.72 & 0.0188 & 0.94 \\
\hline 2 & $1: 3$ & $7.5: 22.5$ & 2.00 & 0.0250 & 1.25 & 0.0156 & 0.78 & 0.0212 & 1.06 \\
\hline 3 & $1: 2$ & 10:20 & 2.00 & 0.0276 & 1.38 & 0.0180 & 0.90 & 0.0242 & 1.21 \\
\hline 4 & $1: 1$ & $15: 15$ & 2.00 & 0.0402 & 2.01 & 0.0286 & 1.43 & 0.0362 & 1.81 \\
\hline 5 & $2: 1$ & 20:10 & 2.00 & 0.0260 & 1.30 & 0.0184 & 0.92 & 0.0238 & 1.19 \\
\hline 6 & $3: 1$ & 22.5:7.5 & 2.00 & 0.0346 & 1.73 & 0.0230 & 1.15 & 0.0258 & 1.29 \\
\hline 7 & 1:0 & $30: 0$ & 2.00 & 0.0630 & 3.15 & 0.0412 & 2.06 & 0.0506 & 2.53 \\
\hline
\end{tabular}

TABLE III

Heavy organics (HO) precipitated from Wellhead (WH), Separator (SR) and Flowline (FL) crude oil samples of SAPW2 by changes in ratios of $\mathbf{n}-\mathbf{C}_{5}: \mathbf{C}_{6}$ binary mixtures.

\section{SAPW2 wellhead}

(WH)
Wt. of Wt. of $\mathrm{HO}$ crude(g) ppt. (g)

$\begin{array}{lcc}\text { Test } & \text { Ratios } & \text { v/v ratio } \\ \text { S/N } & \mathrm{C}_{5}: \mathrm{C}_{6} & \mathrm{C}_{5}: \mathrm{C}_{6}\end{array}$

$1 \quad 0: 1$

$2 \quad 1: 3$

$0: 30$

2.00

0.0178

Wt. $\% \mathrm{HO}$

$3 \quad 1: 2$

$4 \quad 1: 1$

7.5:22.5

2.00

0.0186

ppt. (\%)

10:20

2.00

0.0229

15:15

2.00

0.0346

0.0232

0.0296

0.0439
SAPW2 Separator

(SR)

Wt. of HO ppt. (g) 0.89

0.93

1.15

1.73

1.16

1.48

2.20
0.0101

0.0116

0.0120

0.0190

0.0125

0.0139

0.0239
SAPW2 Flowline

(FL)

$\mathrm{Wt} \% \quad \mathrm{Wt}$.

HO ppt. ofHO

Wt.\%

ppt. (g) (\%)

$\begin{array}{lll}0.51 & 0.0166 & 0.83\end{array}$

$\begin{array}{lll}0.58 & 0.0175 & 0.88\end{array}$

$\begin{array}{lll}0.60 \quad 0.0211 & 1.06\end{array}$

$\begin{array}{lll}0.95 & 0.0288 & 1.44\end{array}$

$\begin{array}{lll}0.63 & 0.0213 & 1.07\end{array}$

$\begin{array}{lll}0.70 & 0.0262 & 1.31\end{array}$

$\begin{array}{lll}1.20 & 0.0316 & 1.58\end{array}$ 


\section{International Advanced Research Journal in Science, Engineering and Technology \\ ISO 3297:2007 Certified \\ Vol. 5, Issue 1, January 2018}

\section{TABLE IV}

Heavy organics (HO) precipitated from Wellhead (WH), Separator (SR) and Flowline (FL) crude oil samples of SAPW3 by changes in ratios of $\mathbf{n}-\mathbf{C}_{5}: \mathbf{C}_{6}$ binary mixtures.

\begin{tabular}{cccccccccc} 
& & & \multicolumn{3}{c}{ SAPW3 wellhead (WH) } & \multicolumn{2}{c}{$\begin{array}{c}\text { SAPW Separator } \\
\text { (SR) }\end{array}$} & \multicolumn{2}{c}{$\begin{array}{c}\text { SAPW3 Flowline } \\
\text { (FL) }\end{array}$} \\
$\begin{array}{c}\text { Test } \\
\text { S/N }\end{array}$ & $\begin{array}{c}\text { Ratios } \\
\mathbf{C}_{\mathbf{5}}: \mathbf{C}_{\mathbf{6}}\end{array}$ & $\begin{array}{c}\text { v/v ratio } \\
\mathbf{C}_{\mathbf{5}}: \mathbf{C}_{\mathbf{6}}\end{array}$ & $\begin{array}{c}\text { Wt. of } \\
\text { crude(g) }\end{array}$ & $\begin{array}{c}\text { Wt. of HO } \\
\text { ppt. (g) }\end{array}$ & $\begin{array}{c}\text { Wt.\% HO } \\
\text { ppt. (\%) }\end{array}$ & $\begin{array}{c}\text { Wt. of } \\
\text { HO ppt. } \\
(\mathrm{g})\end{array}$ & $\begin{array}{c}\text { Wt.\% } \\
\text { HO ppt. } \\
(\%)\end{array}$ & $\begin{array}{c}\text { Wt. ofHO } \\
\text { ppt. (g) }\end{array}$ & $\begin{array}{c}\text { Wt.\% HO } \\
\text { ppt. (\%) }\end{array}$ \\
1 & $0: 1$ & $0: 30$ & 2.00 & 0.0158 & 0.79 & 0.0106 & 0.53 & 0.0130 & 0.65 \\
2 & $1: 3$ & $7.5: 22.5$ & 2.00 & 0.0178 & 0.89 & 0.0108 & 0.54 & $0 . .0140$ & 0.70 \\
3 & $1: 2$ & $10: 20$ & 2.00 & 0.0246 & 1.23 & 0.0182 & 0.91 & 0.0220 & 1.10 \\
4 & $1: 1$ & $15: 15$ & 2.00 & 0.0396 & 1.98 & 0.0270 & 1.35 & 0.0350 & 1.65 \\
5 & $2: 1$ & $20: 10$ & 2.00 & 0.0260 & 1.30 & 0.0218 & 1.09 & 0.0246 & 1.23 \\
6 & $3: 1$ & $22.5: 7.5$ & 2.00 & 0.0370 & 1.85 & 0.0240 & 1.20 & 0.0318 & 1.59 \\
7 & $1: 0$ & $30: 0$ & 2.00 & 0.0490 & 2.45 & 0.0416 & 2.08 & 0.0460 & 2.30
\end{tabular}

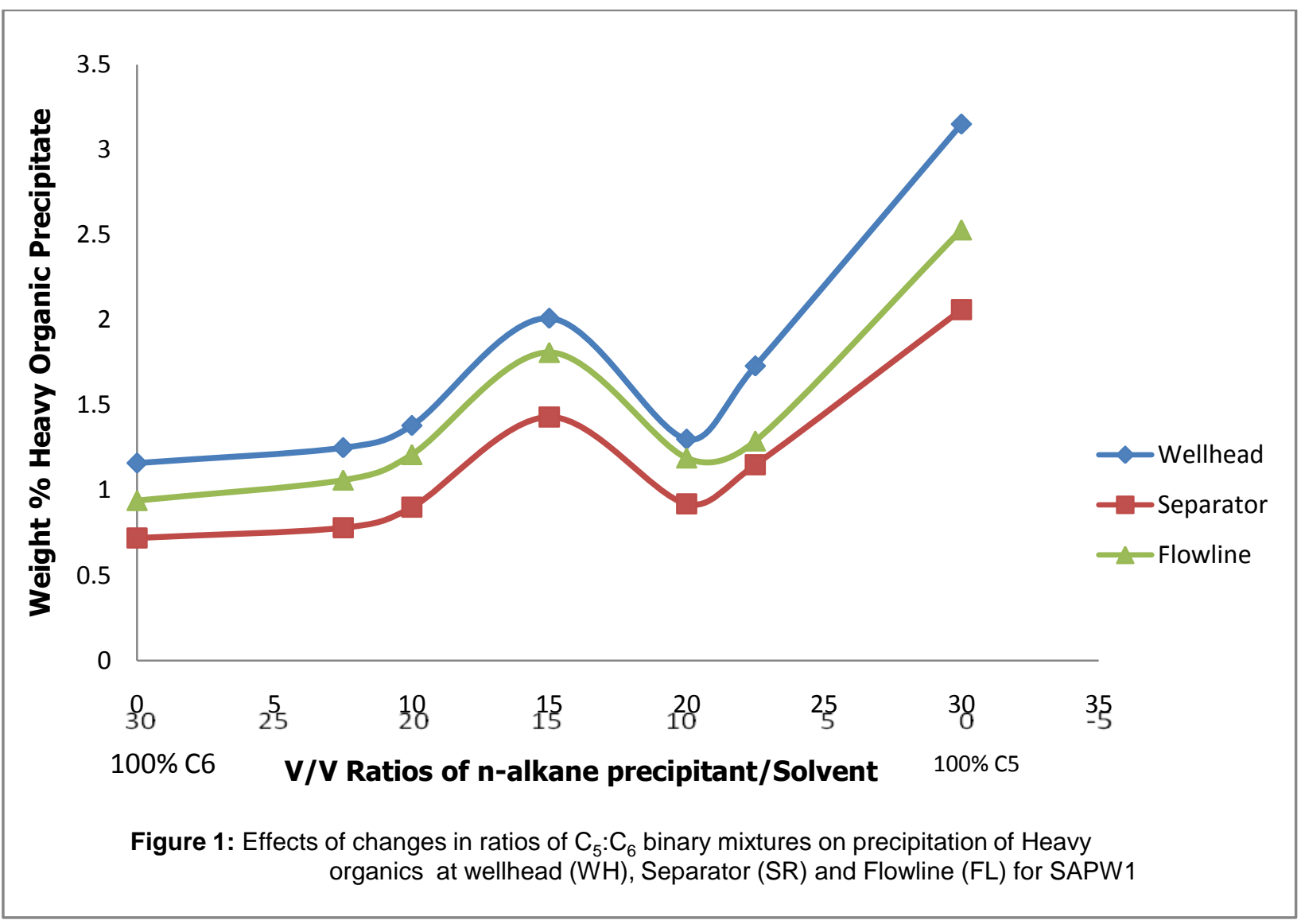


International Advanced Research Journal in Science, Engineering and Technology

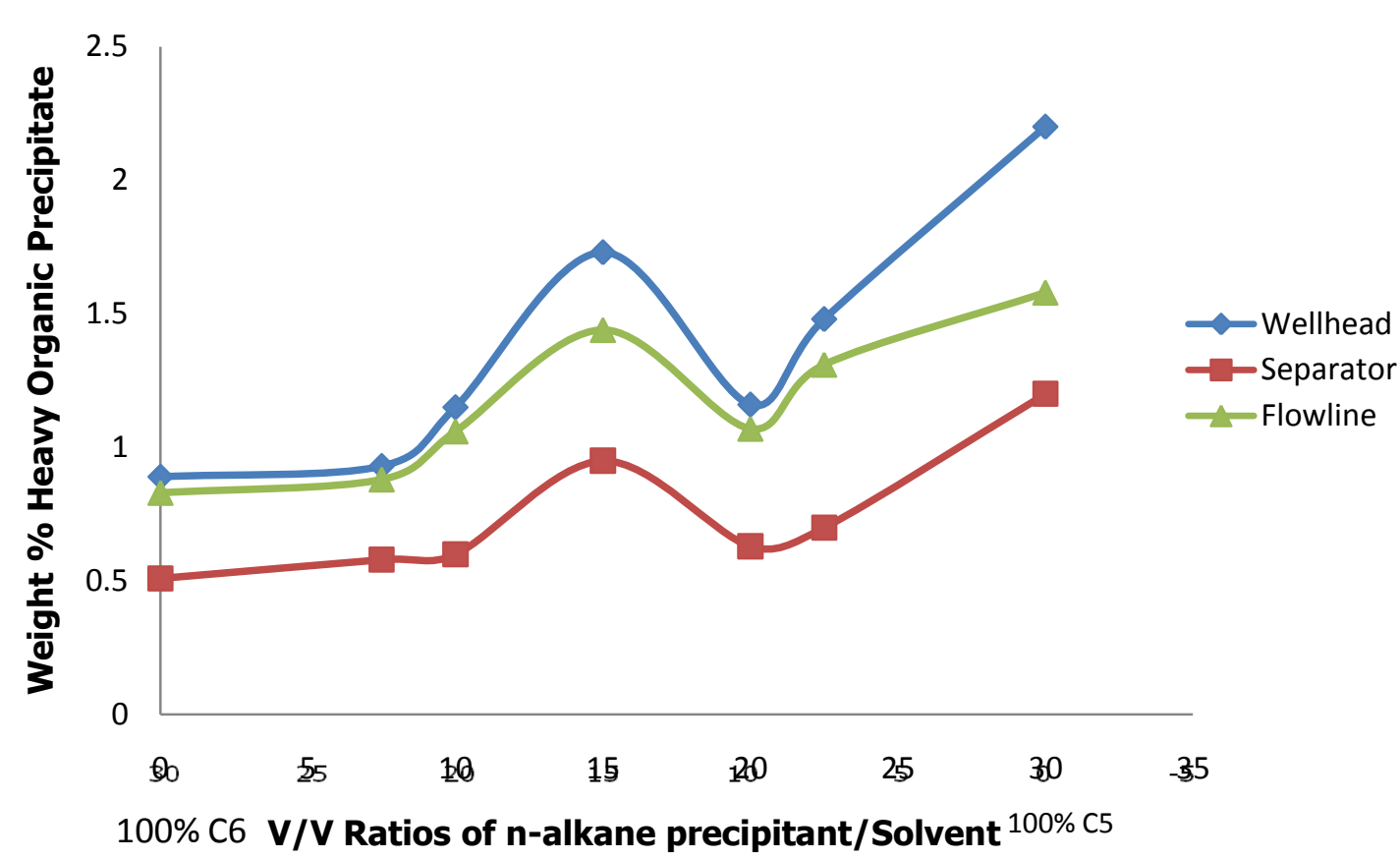

Figure 2: Effects of changes in ratios of $C_{5}: C_{6}$ binary mixtures on precipitation of Heavy organics at wellhead (WH), Separator (SR) and Flowline (FL) for SAPW2

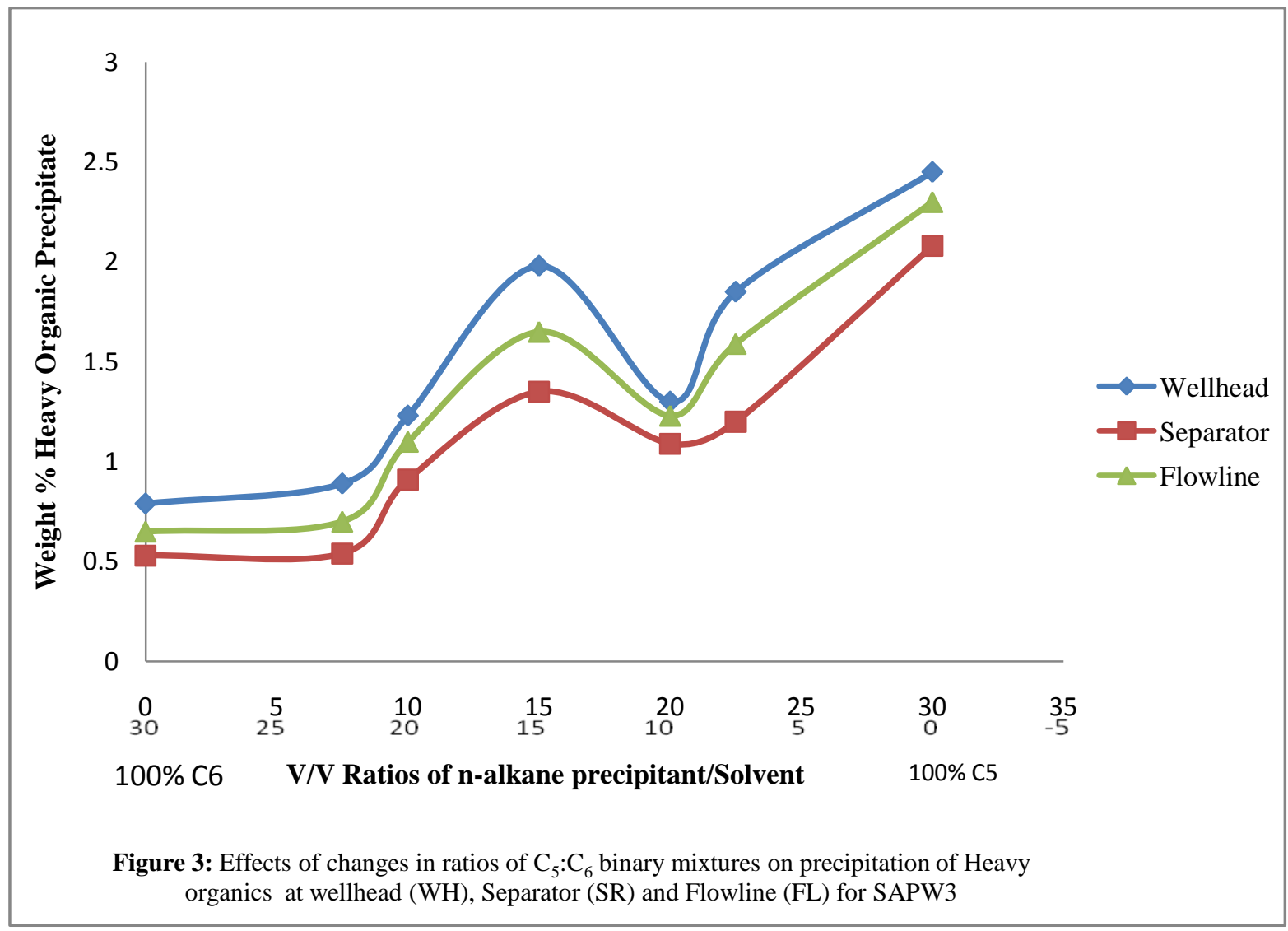




\section{International Advanced Research Journal in Science, Engineering and Technology \\ ISO 3297:2007 Certified}

Vol. 5, Issue 1, January 2018

\section{REFERENCES}

[1] E. Buenrostro-Gonzalez, C. Lira-Galeana, A. A. Gil-Villegas and J. Wu. Asphaltene precipitation in crude oils: Theory and experiments, American Institute of Chemical Engineers (AIChE) Journal, 50(10), 2004, 2552-2570.

[2] S. Kokal, M. Al-Dokhi and S. Sayegh. Phase behavior of a gas-condensate/water system, SPE Reservoir Evaluation \& Engineering, 6(06), 2003, 412-420.

[3] G. A. Mansoori. Asphaltene, resin, and wax deposition from petroleum fluids: Mechanisms and modeling, Arabian Journal for Science and Engineering, 21(4997), 1996, 707-723.

[4] M. C. Utin, S. E. Ofodile, R. E. Ogali and O. Achugasim. Resins in the Heavy Organics Precipitate from Crude Oil with Single n-Alkane and Binary Mixture n-Alkane Solvents, International Journal of Scientific and Technology Research, 6(3), 2017, 39-42.

[5] G. A. Mansoori. Modeling of asphaltene and other heavy organic depositions, Journal of petroleum science and engineering, 17(1-2), 1997, $101-111$.

[6] V. A. M. Branco, G. A. Mansoori, L. C. D. A. Xavier, S. J. Park and H. Manafi. Asphaltene flocculation and collapse from petroleum fluids, Journal of Petroleum Science and Engineering, 32(2), 2001, 217-230.

[7] S. T. Dubey and M. H. Waxman. Asphaltene adsorption and desorption from mineral surfaces, SPE Reservoir Engineering, 6(03), $1991,389-395$.

[8] I. Iroegbu, R. E. Ogali, S. E. Ofodile and O. Achugasim. Heavy organics precipitation: Effect of different volume ratios of low molecular weight N-Alkane in ternary mixtures at a fixed total volume, International Journal of Chemical Studies IJCS, 5(1), $2017,12-17$.

[9] S. L. Kokal, J. Najman, S. G. Sayegh and A. E. George. Measurement and correlation of asphaltene precipitation from heavy oils by gas injection, Journal of Canadian Petroleum Technology, 31(04), 1992, 8-19.

[10] V. O. Njiofor. Precipitation of Heavy Organics from a Crude oil Residue using Binary Mixtures of n-alkane solvents, M.Sc. Thesis, University of Port Harcourt, Port Harcourt, Nigeria. 2012.

[11] G. A. Udourioh, M. U. Ibezim-Ezeani, and S. E. Ofodile. The Effect of Compositional Changes of Binary Mixtures of n-alkane solvents on the Precipitation of Heavy Organics from a Solution of Crude Oil Residue, Journal of Applied Sciences and Environmental Management, 19(3), 2015, 549-554.

[12] T. F Yen and G. V. Chilingarian. Roles of Asphaltenes on Oil Recovery and Mathematical Modelling of Asphaltene Properties - In Asphaltenes and asphalts, Developments in Petroleum Science, 1(40), 1994, 249-274.

[13] J. Escobedo and G. A. Mansoori. Viscometric principles of onsets of colloidal asphaltene flocculation in paraffinic oils and asphaltene micellization in aromatics, SPE Production and Facilities, 12(02), 1997, 116-122.

[14] S. Kawanaka, S. J. Park and G. A. Mansoori. Organic deposition from reservoir fluids: a thermodynamic predictive technique. SPE Reservoir Engineering, 6(02), 1991, 185-192.

[15] G. A. Udourioh, M. I. Ibezim-Ezeani and, S. E. Ofodile. Comparative investigation of heavy organics precipitation from crude oil using binary mixtures and single n-alkane organic solvents, Journal of Petroleum and Gas Exploration Research, 4(4), 2014, 53-59. 